\title{
Grape variety affects larval performance and also female reproductive performance of the European grapevine moth Lobesia botrana (Lepidoptera: Tortricidae)
}

\author{
J. Moreau ${ }^{1} \dagger$, B. Benrey ${ }^{1}$ and D. Thiéry ${ }^{2 *}$ \\ ${ }^{1}$ Institut de Zoologie, Université de Neuchâtel, CH-2007 Neuchâtel, \\ Switzerland: ${ }^{2}$ UMR 1065 INRA-ENITAB en Santé Végétale, INRA, Institut \\ Supérieur de la Vigne et du Vin, BP 81, F-33883 Villenave d'Ornon \\ Cedex, France
}

\begin{abstract}
For insect herbivores, the quality of the larval host plant is a key determinant of fitness. Therefore, insect populations are supposed to be positively correlated with the nutritional quality of their host plant. This study aimed to determine if and how different varieties of grapes (including the wild grape Lambrusque) affect both larval and adult performance of the polyphagous European grapevine moth Lobesia botrana (Denis \& Schiffermüller). Significant differences were found in larval development time, but not in pupal mass, adult emergence rate, or sex ratio. Although the fecundity of females is not different among varieties, females fed on some varieties produced eggs of different sizes which are correlated to their fertility. Thus, females adapt resource allocation to eggs depending on their diet as larvae. Using a fitness index, the average reproductive output was found to be highest for females reared on cv. Chardonnay. Females reared on wild grape produced a fitness index identical to the cultivated grapes. However, Lambrusque and Gewurztraminer separate themselves from the cultivated varieties according to our discriminant analyses. It is emphasized, through this study, that cultivars fed on by larvae should be considered in the population dynamics of L. botrana and that egg number is insufficient to determine host plant quality.
\end{abstract}

Keywords: female reproductive output, fitness, host plant selection, insect-plant relationships, larval food

\section{Introduction}

The demography of phytophagous insect populations is determined by critical factors, such as abiotic environmental variables (Leather \& Dixon, 1982; Ratte, 1985; Leather, 1995), adult weight (Dixon, 1987) and larval and adult food supply

*Author for correspondence

Fax: + 33(0)557122621

E-mail: thiery@bordeaux.inra.fr

†Present address: Université de Bourgogne, Equipe Ecologie-Evolution, UMR 5561, Biogéosciences, 6 Bd Gabriel, F-21000 Dijon, France
(Scriber \& Slansky, 1981; Leather, 1995) being directly related with the nutritional quality of the host plant. In nature, the nutritional quality of plants varies naturally among plant species and also among varieties within cultivated species (Van Emden, 1987). This variation influences both larval performance and female reproductive output of herbivorous insects (see Awmack \& Leather, 2002 for a review or Kaspi et al., 2002 for an example). Particularly, for most herbivorous insects that are considered capital breeders (species with non-feeding adults) host plant quality is a key determinant of their fitness since they have a reproductive potential limited by the resources accumulated during their larval stages (Slansky \& Rodriguez, 1987; Awmack \& Leather, 2002). Therefore, the density of insect populations 
is supposed to be positively correlated with the nutritional quality of their host plant as larvae.

As a model phytophagous insect we used the European grapevine moth Lobesia botrana (Denis \& Schiffermueller) (Lepidoptera: Tortricidae), the most harmful pest of grapes in Europe, North Africa and West Asia, and it can develop on c. 30 host plants including grapes (Bovey, 1966; Roehrich \& Boller, 1991; Thiéry, 2005). In regions of wine production, some cultivars suffer more damage than others. A differential susceptibility of grape cultivars to L. botrana has been reported (Marchal, 1912; Stellwaag, 1928) and recent studies have attributed this variable susceptibility either to differences in larval settlement (Gabel \& Roehrich, 1995; Fermaud, 1998) or to oviposition preferences for certain varieties (Thiéry \& Gabel, 2000; Maher et al., 2001; Maher \& Thiéry, 2004). In the particular case of the ancestor of European cultivated grapevines (Vitis vinifera sylvestris, Gmelin, called 'Lambrusque') (Scossiroli, 1988; Heywood \& Zohary, 1995), found in several Mediterranean regions and in south west of France, we never observed any damage by L. botrana. This observation is supported by the low levels of injury caused by insect pests on wild grapes in general (Ocete et al., 1997; Arnold, 1999; J. Moreau, personal observation).

In order to explain why some cultivars suffer more damage by L. botrana than others, we tested if different cultivars of grapes affect the reproductive strategy of this pest. We also tested whether Lambrusque (wild grape) is less suitable for L. botrana than cultivated grape, explaining why L. botrana larvae are never found on this wild grape. Performance on four cultivated grape varieties (Chardonnay, Chasselas, Gewurztraminer and Grenache) and the wild ancestor of grapes (Lambrusque) were examined by measuring the complete suite of life history traits of L. botrana, from egg hatching to individual death in order to calculate the fitness of females fed as larvae on these different varieties. Pupal mass, larval development time and larval survival were recorded, and the influence of plant quality on reproductive success was also determmined, by measuring mating success fecundity, egg size, egg hatchability and adult longevity.

\section{Materials and methods}

\section{Study system: moths, their origin and maintenance}

A strain of L. botrana (INRA Bordeaux) originating from individuals collected in a French Sauternes vineyard (cultivar White Sauvignon) was used. The stock colony is maintained without diapause for about 20 generations on a semi-artificial diet at $24 \pm 1^{\circ} \mathrm{C}, 60 \pm 10 \%$ r.h. with a photoperiod of L15:D $8+1 \mathrm{~h}$ of dusk. The first 15 photophase hours were at 1000 lux luminosity and the last one (dusk) at 25 lux. All tests were performed under these same conditions.

\section{Larval diet treatments and general procedure}

All the cultivars were compared using a standardized procedure similar to that described elsewhere (Thiéry \& Moreau, 2005). This procedure is on artificial Lepidoptera medium in which freeze-dried powder of plant material is incorporated. This presents at least three main advantages: (i) feeding larvae in isolation thus preventing biases due to competition and subsequent food deprivation; preventing differences in bunch compactness, which has an effect on larval feeding behaviour (our unpublished observations); and (iii) preventing incidences of infections by fungi which naturally grow on harvested bunches and can modify larval fitness (Savopoulou-Soultani \& Tzanakakis, 1988; Mondy \& Corio-Costet, 2000). Larvae were raised individually to pupation in Eppendorf tubes filled with $1.5 \mathrm{ml}$ of a medium composed of: $150 \mathrm{ml}$ water, $5 \mathrm{~g}$ agar, $6 \mathrm{~g}$ cellulose powder, $7 \mathrm{~g}$ casein, $4 \mathrm{~g}$ vitamin-free casein, $3.5 \mathrm{~g}$ glucose, $2 \mathrm{~g}$ mineral salt, $0.12 \mathrm{~g}$ cholesterol, $0.12 \mathrm{~g}$ maize oil, $0.25 \mathrm{~g}$ benzoic acid, $0.1 \mathrm{~g}$ nipagine, $0.007 \mathrm{~g}$ tetracycline and $12 \mathrm{~g}$ freeze-dried plant powder. The plant powder was obtained from bunches of $V$. vinifera cv. Chasselas, Chardonnay, Gewurztraminer, Grenache or Lambrusque, wild grape, which were all harvested from the gene bank collection 'Domaine de la Grande Ferrade', at INRA Bordeaux. The bunches were collected at the beginning of the growing season (beginning of May 2003), all at phenological stages 23-27 (Eichhorn \& Lorenz, 1977), which correspond to the grape phenology when the first generation of L. botrana occurs in the year.

The Eppendorf lids were pierced to allow air circulation. Using a fine brush, an individual newly-hatched larva (age $<24 \mathrm{~h}$ ) was transferred to each of 100 Eppendorfs per grape variety diet.

\section{Growth and development}

Larvae were monitored daily until pupation; pupae were then gently removed from the diet and weighed to the nearest $0.1 \mathrm{mg}$. The weight of live pupae was used as an index of body size. Pupae were placed individually in glass tubes $(70 \mathrm{~mm} \times 9 \mathrm{~mm}$ diameter), which were sealed with a cotton plug and stored in the test room until emergence. Adults were sexed upon emergence. The following variables were recorded: (i) total survival (larval and pupal) (=percentage adult emergence); (ii) pupal mass; (iii) total development time (larval and pupal); and (iv) adult sex-ratio.

\section{Reproductive life history traits}

Adults resulting from the five larval diets were used to evaluate the reproductive output of females. Newly emerged (less than 1-day-old) females were individually confined in 0.51 transparent cellophane bags as mating and oviposition chambers and provided with water ad libitum through a soaked cotton dental wick. One- or two-day-old virgin males originating from the same diet were added to each caged virgin female, $1 \mathrm{~h}$ before dusk, the period of sexual activity (Bovey, 1966). Within a treatment, males were considered equivalent and thus were randomly assigned to females. Pairs were caged in these bags until the death of both sexes. At the end of the experiment, eggs on the cellophane bags were counted and measured with an ocular micrometer. Their surface (estimated as an elliptic surface, $\mathrm{S}=\pi \times a \times b$ $\left(\mathrm{mm}^{2}\right)$, where $a$ and $b$ are the ellipse semiaxes) was used as an index of egg size. Mean egg size was estimated for each female from a randomly chosen sample of 15 eggs from her total egg production. To determine fertility, all eggs were incubated at $22^{\circ} \mathrm{C}$ for 10 days until hatching, and the number of hatched eggs was counted.

Seven variables were considered: (i) percentage of mated female (female mating success) assessed by production of at 
Table 1. Developmental life history traits of Lobesia botrana raised on different grape cultivars.

\begin{tabular}{|c|c|c|c|c|c|c|}
\hline \multirow[t]{2}{*}{ Grape cultivar } & \multirow[t]{2}{*}{$\begin{array}{l}\text { \% of emergence } \\
\text { (= larval survival) }\end{array}$} & \multirow[t]{2}{*}{$\begin{array}{c}\text { Sex-ratio } \\
\text { (\% of females) }\end{array}$} & \multicolumn{2}{|c|}{$\begin{array}{l}\text { Development time } \\
\text { (days) mean } \pm \text { S.E.M. }\end{array}$} & \multicolumn{2}{|c|}{$\begin{array}{l}\text { Pupal mass }(\mathrm{mg}) \\
\text { mean } \pm \text { S.E.M. }\end{array}$} \\
\hline & & & Males & Females & Males & Females \\
\hline Chardonnay & 91 & 57.14 & $27.92 \pm 0.45 \mathrm{BC}$ & $29.63 \pm 0.23 \mathrm{~B}$ & $9.94 \pm 0.21$ & $14.24 \pm 0.33$ \\
\hline Chasselas & 90 & 51.11 & $28.36 \pm 0.34 \mathrm{~B}$ & $30.43 \pm 0.23 B$ & $9.59 \pm 0.29$ & $13.92 \pm 0.36$ \\
\hline Gewurztraminer & 87 & 49.42 & $29.64 \pm 0.28 \mathrm{~A}$ & $32.23 \pm 0.31 \mathrm{~A}$ & $9.98 \pm 0.25$ & $15.06 \pm 0.36$ \\
\hline Grenache & 86 & 44.18 & $26.92 \pm 0.18 \mathrm{C}$ & $29.89 \pm 0.23 B$ & $10.13 \pm 0.17$ & $13.89 \pm 0.34$ \\
\hline Lambrusque & 84 & 53.57 & $27.00 \pm 0.34 \mathrm{C}$ & $29.27 \pm 0.33 C$ & $9.80 \pm 0.31$ & $14.06 \pm 0.29$ \\
\hline$\chi_{4}^{2}$ & $3.05^{\mathrm{a}}$ & $3.28^{\mathrm{a}}$ & $54.07^{\mathrm{b}}$ & $55.91^{\mathrm{b}}$ & $0.64^{\mathrm{b}}$ & $5.26^{\mathrm{b}}$ \\
\hline$\stackrel{P}{P}$ & 0.55 & 0.51 & $<0.0001$ & $<0.0001$ & 0.96 & 0.26 \\
\hline
\end{tabular}

100 larvae per cultivar. Values (mean \pm S.E.M.) in each column with the same letter are not significantly different $(P>0.05)$ after a nonparametric PLSD test.

${ }^{\mathrm{a}}$ Pearson $\chi^{2}$; ${ }^{\mathrm{b}}$ Kruskal-Wallis test.

least five fertile eggs during her lifetime (non-mated females are able to lay some infertile eggs at the end of their life); (ii) delay before the first egg laid (days); (iii) total achieved fecundity (mean number of eggs laid); (iv) duration of laying (days); (v) mean egg size; (vi) total number of viable eggs (=female fertility); and (vii) longevity of mated females.

\section{Statistical analysis}

The statistical tests were performed using the JMP software (Version 3.2.2, SAS Institute Inc.). A stepwise analysis (backward procedure) was used to remove nonsignificant effects and interactions (at $P>0.05$ ) and only the resulting models are presented here. Kruskal-Wallis or Wilcoxon Rank Sum non-parametric tests were used when data did not meet normality (Shapiro-Wilk's test) or homogeneity of variances assumptions (Levene's test) and when attempts to fit data to normal distributions failed. Two-tailed tests of significance were used throughout. A discriminant analysis was used to select the core variables that are pertinent to describe the interrelationships. A stepwise discriminant analysis was carried out using a 'forward' procedure, which begins with no variables in the model and adds the variables with the greatest discriminating power (see Legendre \& Legendre, 1998 for statistical details). This analysis selects the variables that describe differentiation among cultivars. The input parameters for the discriminant analysis were group variables (Chardonnay, Chasselas, Gewurztraminer, Grenache and Lambrusque) and continuous independent variables (all continuous life history traits measured during experiments).

\section{Results}

Growth and development

The percentage of moths that emerged (equivalent to larval survival) from the five cultivars was not significantly different (almost $90 \%$ of larvae reached the adult stage) and there was no effect of diet on the sex ratio of the emerging adults (table 1). Among the emerging adults, the developmental time of males was significantly shorter than that of females, and developmental time of both sexes varied slightly but significantly among the cultivars on which larvae were fed (two-way ANOVA: general model: $F_{5,437}=52.81, P<0.0001$; effect of cultivar: $F_{4,437}=28.45$, $P<0.0001$; effect of sex: $\left.F_{1,437}=151.89, P<0.0001\right)$. Although differences were found in developmental time among larvae fed on different cultivars, the resulting pupae (male and female) exhibited similar weight (table 1). However, females were always heavier than males, independent of cultivars and the pupal mass of both sexes was independent with their development duration (three-way ANOVA: general model: $F_{6,437}=91.83, P<0.0001$; effect of sex: $F_{1,437}=457.38$, $P<0.0001$; effect of cultivar: $F_{4,437}=1.21, P=0.13$; effect of duration of larval development: $F_{1,437}=1.45, P=0.10$ ).

\section{Reproduction}

Female mating success, measured as the number of females that produced viable eggs, ranged from $70 \%$ to $84 \%$, and was not significantly different among cultivars (table 2). Among mated females, the delay between encountering a mate and the first egg laid was around 4 days and was also

Table 2. Reproductive life history traits of adult female Lobesia botrana according to the grape cultivar on which the larvae developed.

\begin{tabular}{lccccc}
\hline Grape cultivar & $\begin{array}{c}\text { No. of female } \\
\text { tested }\end{array}$ & $\begin{array}{c}\text { \% of mated } \\
\text { females }\end{array}$ & $\begin{array}{c}\text { Delay before the } \\
\text { first egg (days) }\end{array}$ & $\begin{array}{c}\text { Duration of } \\
\text { laying (days) }\end{array}$ & $\begin{array}{c}\text { Longevity of mated } \\
\text { females (days) }\end{array}$ \\
\hline Chardonnay & 50 & 84.00 & $4.81 \pm 0.46$ & $5.40 \pm 0.33$ & $10.21 \pm 0.30$ \\
Chasselas & 45 & 73.33 & $4.94 \pm 0.43$ & $5.39 \pm 0.31$ & $10.33 \pm 0.36$ \\
Gewurztraminer & 40 & 70.00 & $4.25 \pm 0.46$ & $4.93 \pm 0.23$ & $9.18 \pm 0.43$ \\
Grenache & 36 & 72.22 & $4.42 \pm 0.44$ & $5.77 \pm 0.38$ & $10.19 \pm 0.38$ \\
Lambrusque & 45 & 77.78 & $4.32 \pm 0.33$ & $5.82 \pm 0.19$ & $10.00 \pm 0.35$ \\
$\chi^{2}{ }_{4}$ & & $3.07^{\mathrm{a}}$ & $2.00^{\mathrm{b}}$ & $7.71^{\mathrm{b}}$ & $8.98^{\mathrm{b}}$ \\
& & 0.55 & 0.74 & 0.10 & 0.06 \\
\hline
\end{tabular}

Values (mean \pm S.E.M.) in each column with the same letter are not significantly different $(P>0.05)$ after a non-parametric PLSD test. ${ }^{\mathrm{a}}$ Pearson $\chi^{2},{ }^{\mathrm{b}}$ Kruskal-Wallis test. 

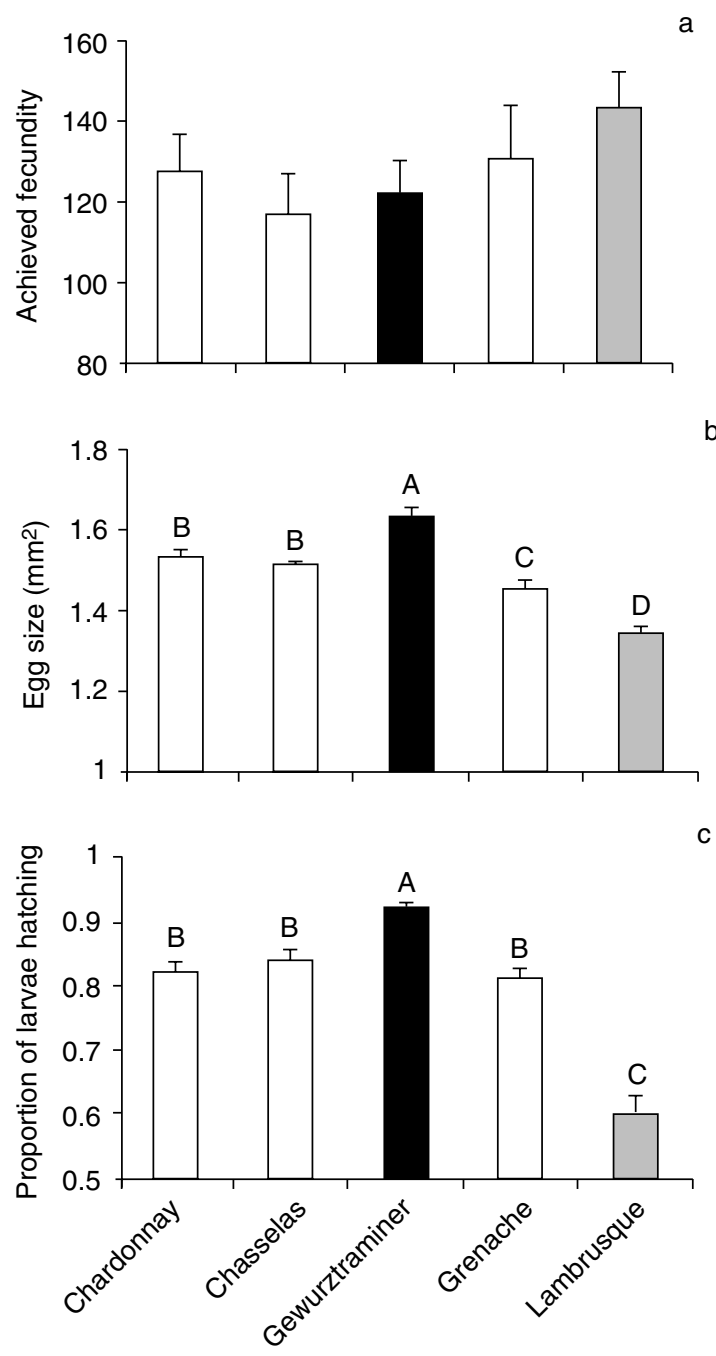

Fig. 1. (a) Achieved fecundity (mean \pm S.E.M.), (b) size of eggs laid (mean \pm S.E.M.) and, (c) proportion of larvae hatching from Lobesia botrana females, reared on different grape cultivars. The colour of columns is arranged according to the groups defined by the female development time in table $1: \mathbf{\square}$, cultivars that promote a slow larval development; $\square$ cultivars that promote a fast larval development; $\square$, cultivars that promote an intermediate larval development. Columns with the same capital letter are not significantly different $(P>0.05)$ after a nonparametric PLSD test. not influenced by larval food (table 2). The total number of eggs laid per female was not affected by the origin of females (fig. 1a, Kruskal-Wallis test, $\chi^{2}{ }_{4}=4.83, P=0.31$ ). The number of eggs laid by a given female was positively correlated with her pupal mass and negatively correlated with the delay before the first egg laid, but there was no correlation with egg-laying duration (three-way ANOVA: general model: $F_{3,162}=111.20, P<0.0001$; effect of pupal weight: $F_{1,162}=$ 43.52, $P<0.0001$; effect of duration of egg laying: $F_{1,162}=0.52$, $P=0.47$; effect of delay: $F_{1,162}=171.89, P<0.0001$ ) (table 2). In contrast to fecundity, egg size and the proportion of larvae hatching were strongly affected by the cultivars on which females fed as larvae (fig. 1b, Kruskal-Wallis test, $\chi^{2}{ }_{4}=73.81$, $P<0.0001$; fig. 1c, Kruskal-Wallis test, $\chi_{4}^{2}=68.23, P<0.0001$ ). Interestingly, egg size was correlated with the duration of the female's development (linear regression: $F_{1,163}=13.26$, $\left.P=0.0004, \mathrm{r}^{2}=0.58\right)$. In other words, the longer the female's larval and pupal stages were, the bigger were her eggs. Fertility was also positively correlated with egg size and development time (two-way ANOVA: general model: $F_{2,163}=32.51, \quad P<0.0001$; effect of egg size: $F_{1,163}=39.44$, $P<0.0001$; effect of larval development time: $F_{1,163}=9.83$, $P=0.002$ ). Thus, females raised on Gewurztraminer (which promoted a long larval development) laid the largest and most viable eggs, whereas females raised on Lambrusque (which promoted fast larval development) laid the smallest and least viable eggs (fig. $1 \mathrm{~b}, \mathrm{c}$ ). The three other cultivars were relatively similar. Finally, the longevity of mated females was not different among cultivars (table 2).

\section{Evaluation of fitness in L. botrana}

The life history traits assessed during this study allowed us to estimate the fitness of L. botrana females. By using the fecundity and hatching rate, the mean number of larvae produced per mated female was calculated. From this, the number of females emerged was calculated by using larval and pupal mortality and the sex ratio. Finally, from the mating success, the number of mated females that contributed to the production of the next generation was calculated. This estimation was then used as an overall measure of fitness (=Fitness Index). The estimates for females that were reared on Chardonnay were higher than for those reared on the four other cultivars (Kruskall-Wallis Test, $\left.\chi_{4}^{2}=15.85, P=0.003\right)$. Interestingly, the fitness index of females reared on Lambrusque (wild grapes) was very similar to three other cultivars (table 3).

Table 3. Number of estimated females (mean \pm S.E.M.) participating in reproduction in the next generation of Lobesia botrana according to the grape cultivar on which the larvae developed and according to the life history traits assessed.

\begin{tabular}{|c|c|c|c|c|c|}
\hline Grape cultivar & $\begin{array}{l}\text { No. of larvae produced } \\
\text { for all females mated } \\
\text { (fecundity } \times \text { hatch } \\
\text { rate used })\end{array}$ & $\begin{array}{l}\text { No. of adults } \\
\text { emerging ( } \% \text { of } \\
\text { emergence used) }\end{array}$ & $\begin{array}{l}\text { No. of females } \\
\text { (sex-ratio } \\
\text { used) }\end{array}$ & $\begin{array}{c}\text { No. of females participating } \\
\text { to the reproduction (mating } \\
\text { success used)= Fitness } \\
\text { Index }\end{array}$ & $\begin{array}{l}\text { PLSD Test after } \\
\text { Kruskall-Wallis } \\
\text { tests on } \\
\text { Fitness Index }\end{array}$ \\
\hline Chardonnay & $104.95 \pm 8.06$ & $95.50 \pm 7.34$ & $54.44 \pm 4.18$ & $45.73 \pm 3.51$ & A \\
\hline Chasselas & $98.40 \pm 9.25$ & $88.56 \pm 8.33$ & $45.16 \pm 4.25$ & $32.97 \pm 3.10$ & B \\
\hline Gewurztraminer & $111.83 \pm 8.46$ & $97.29 \pm 6.37$ & $47.67 \pm 3.61$ & $33.37 \pm 2.52$ & B \\
\hline Grenache & $103.61 \pm 10.09$ & $89.11 \pm 8.68$ & $39.21 \pm 3.82$ & $28.23 \pm 2.75$ & $\mathrm{~B}$ \\
\hline Lambrusque & $87.52 \pm 7.03$ & $73.51 \pm 5.98$ & $38.96 \pm 3.13$ & $30.00 \pm 2.41$ & $\mathrm{~B}$ \\
\hline
\end{tabular}


Table 4. Power of discrimination of life history traits driving the discrimination of the five grape cultivars, considered individually and at the end of the analysis.

\begin{tabular}{lcc}
\hline Life history traits & $\begin{array}{c}\text { Exact } F \text { at } \\
\text { last step }\end{array}$ & $P$ \\
\hline Egg size & 17.16 & $<0.001$ \\
Fertility & 12.22 & $<0.001$ \\
Development time & 5.83 & $<0.001$ \\
Duration of laying & 1.75 & 0.14 \\
Longevity & 1.61 & 0.17 \\
Fecundity & 1.19 & 0.31 \\
Delay of laying & 0.62 & 0.65 \\
Pupal mass & 0.15 & 0.96 \\
\hline
\end{tabular}

\section{Discriminant analysis}

A significant discriminant model was obtained when using egg size, fertility, and development time to distinguish among five cultivars (table 4). The graphical representations of the cultivars in the plane defined by the first two canonical functions (fig. 2) shows that Lambrusque (wild grapes) are clearly separated from other cultivars, whereas among cultivated grapes, Gewurztraminer separates itself. In other words, the individuals raised on wild grape exhibited life history traits different to those raised on cultivated grapes (faster development time, smaller eggs and lower proportion of larvae hatching). In addition, among individuals raised on different cultivated grapes differences also exist. Individuals raised on Gewurztraminer exhibited longer development time, larger eggs and a higher proportion of larvae hatching as compared to those raised on the three other cultivars.

\section{Discussion}

In the present study, the different grape varieties used as larval food sources strongly affected development and reproductive life history traits in L. botrana. Females reared on Chasselas, Chardonnay and Grenache exhibited a similar pattern of life history traits as revealed by our discriminant analysis. The two other varieties (Lambrusque and Gewurztraminer) are well separated mainly due to differences in their patterns of egg size, egg hatchability and development time.

Larval development time varied among the five grape varieties, whereas larval mortality, sex ratio and pupal weight were not significantly different among cultivars. Gewurztraminer induced a slower larval development than other cultivars suggesting that this cultivar is of lower nutritional value for larvae of L. botrana. Interestingly, although total development time clearly varied among cultivars, the resulting pupae had similar weights indicating no fitness penalty to speed up the larval development. The classic relationship between size and development time appears in general to be less strict in butterflies than in some other animals due to plasticity in growth rate (Wiklund et al.,

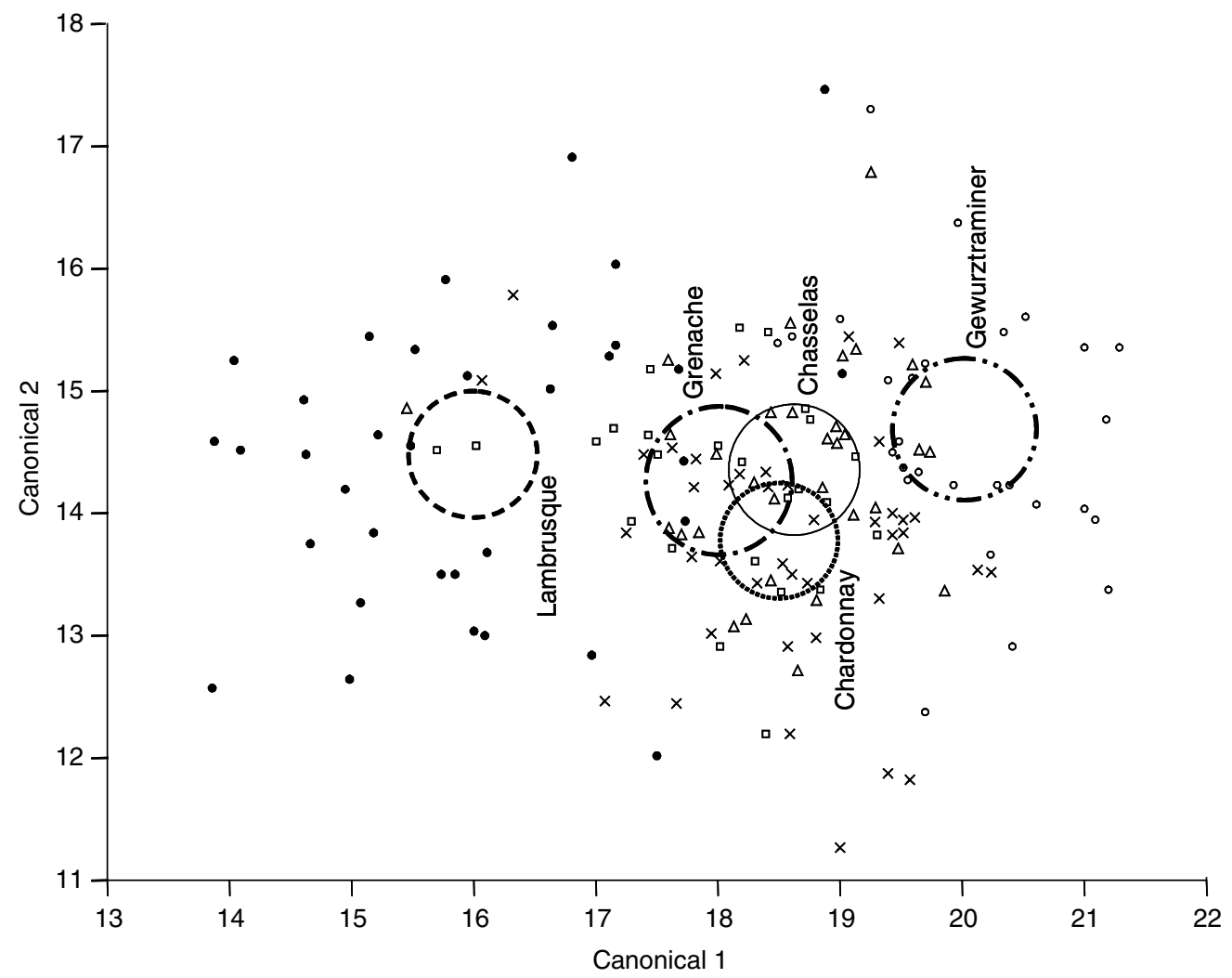

Fig. 2. Visual representation of the results of the stepwise discriminant analysis: position of five cultivars ( $x$, Chardonnnay; $\triangle$, Chasselas; $\bigcirc$, Gewurztraminer; $\square$, Grenache; - Lambrusque) on the plane defined by the canonical variables 1 and 2 . The size of the circle corresponds to a $95 \%$ confidence limit for the mean. Groups that are significantly different have non-intersecting circles. 
1991). Here, prolonged larval development time in Gewurztraminer enabled larvae to compensate for a low consumption rate or for food of poor quality and to finally reach the same weight as larvae that were reared on cultivars that promoted a faster larval development. However, a prolonged development time could be a potentially important component of fitness in nature because it may increase larval exposure to predators and parasites (Weseloh et al. 1983; Benrey \& Denno, 1997; Parry et al., 1998). Females of L. botrana are often heavier and larger than males, a trait that is mainly attributed to the storage of nutrients used for egg production (Raven, 1961; Slansky \& Scriber, 1985). Female larvae certainly achieve a greater size by feeding and developing for a longer period of time (Mackey, 1978; Lederhouse et al., 1982) as observed during the present experiments.

For all grape varieties, the development time of males was significantly shorter than that of females, probably due to different nutritional larval requirements. Consequently, males started to emerge before females, this protandry is commonly found in fruit tortricids and several other Lepidoptera (Rodriguez-del-Bosque et al., 1989; Roehrich \& Boller, 1991; Wiklund et al., 1993). It presents at least two advantages, by maximizing copulation opportunities for a male (reviewed in Wiklund \& Fagerström, 1977; Bulmer, 1983), and minimizing the pre-reproductive period of females so they emerge when most males are available (Fagerström \& Wiklund, 1982). Torres-Vila et al. (1995) showed that three-day-old Lobesia males are the most efficient at mating. Thus, the two days of protandry observed during our experiments represents a potential advantage for the emerging females by minimizing the risk of emergence when no males are present (Fagerström \& Wiklund, 1982).

The results confirm the importance of the larval hostplant for the adult reproductive success and it can be expected that grape variety will affect survival and numbers of $L$. botrana in vineyards. Indeed, although fecundity and the mating success of the resulting adult was not affected by the origin of females, the size of eggs laid, as well their probability of hatching varied among cultivars, supporting the hypothesis that larval food quality is of primary importance for the reproductive performance of this generalist herbivore. The females raised on Gewurztraminer laid larger eggs than others and had a higher fertility. Since females are unfed during the adult stage, the amino acids in egg protein of female moths derive exclusively from the larval diet, as demonstrated by $\mathrm{O}^{\prime}$ Brien et al. (2002) in hawkmoth. Therefore, the availability of essential amino acids in the diet of larvae poses a significant constraint in egg manufacture. On Gewurztraminer, it is possible that females allocate more lipids and proteins to their eggs (consequently, increasing the probability of hatching) than females from other cultivars, which could explain why egg hatchability was positively correlated with egg size. This contradicts a previous study that found no relationships between these two traits in L. botrana (Torres-Vila \& Rodriguez-Molina, 2002) and in other insects (Wiklund \& Persson, 1983; Karlsson \& Wiklund, 1984, 1985). The present study supports the assumption that larger eggs are associated with more nutritional provisions (Berrigan, 1991; Fox \& Czesak, 2000). Further biochemical analyses of egg contents would be necessary, but were not carried out in the present work. Interestingly, the highest fertility was found on the variety where the larvae exhibited the slowest development time. This suggests the existence of plasticity on reproductive strategies associated with immature development duration. It is thus possible that larvae are able to assess the quality of their host-plant as an environmental quality indicator, and then anticipate the food available to the next generation. By doing this, females that encounter, as larvae, a poor-quality host plant (indicated by a prolonged development time), provision their eggs with a large amount of vitellus to enhance larval survival in this adverse environment. In some insects, this phenotypic plasticity is maternally induced: mothers that experience a predictive environmental cue can change their progeny size and quality so that it is best suited to the conditions predicted by that cue (examples reviewed in Mousseau \& Fox, 1998). For example, in the seed beetle Stator limbatus Horn (Coleoptera: Bruchidae), females change the size of the eggs produced in response to host stimuli, so that their progeny are prepared for the host plant upon which they will develop (Fox et al., 1997). However, to produce big eggs may represent a disadvantage when exposed to egg parasitoids (e.g. Trichogramma) or egg predators like pirate bugs or ants. Also faster development may allow larvae to escape parasitism, which would compensate for the trade-off between small eggs and lower fertility.

Despite the fact that the wild grape (Lambrusque) is well separated from other cultivated varieties (mainly due to the pattern of egg size, egg hatchability and development time being different from that on other cultivars), as shown by the discriminant analysis, the present data did not support the prediction that wild grape is less suitable for the performance of L. botrana than cultivated grapes, in contrast to what has been reported for other cultivated crops and associated insect herbivores (Evans, 1993; Idris \& Grafius, 1996; Benrey et al., 1998; Chen \& Welter, 2003). Performance, survival and the fitness index of L. botrana were quite similar on the wild variety and the cultivars. Food quality therefore does not explain why wild grape plants carry no or few insect pests (Ocete et al., 1997; Arnold, 1999).

Due to the variation in life-history traits, whether this results from phenotypic plasticity or not, Chardonnay seems the most suitable of the varieties for the performance of L. botrana, as indicated by the fitness index. Quality of cultivars as larval food should be taken into account as a factor affecting the population dynamics of $L$. botrana. Another key message from the outcome of the present study is that investigations into host-plant quality should extend to the reproductive output of the resulting offspring, whereby not only egg number, but also egg viability should be measured to obtain a more precise estimate of fitness.

In this study we have only considered the direct effects of the host-plant. For an even more complete assessment, further studies should also investigate indirect effects of host plants like its susceptibility to natural enemies, such as predators, parasitoids and pathogens.

\section{Acknowledgements}

This project was funded by the National Centre of Competence in Research (NCCR) Plant Survival, a research programme of the Swiss National Science Foundation. The authors thank Ellie Haine and Ted Turlings for language corrections and their helpful comments on the manuscript, 
Marc-Etienne Toulouse and Anne Xuéreb (INRA Bordeaux) for experimental contributions and Louis Bordenave (INRA Bordeaux) for free access to bunches of grapes collected in the INRA cultivar bank.

\section{References}

Arnold, C. (1999) Ecologie de la vigne sauvage Vitis vinifera L. ss. sylvestris, dans les forêts alluviales et colluviales d'Europe. $\mathrm{PhD}$ thesis, University of Neuchâtel, Switzerland.

Awmack, C.S. \& Leather, S.R. (2002) Host plant quality and fecundity in herbivorous insects. Annual Review of Entomology $47,817-844$.

Benrey, B. \& Denno, R.F. (1997) The slow growth-high mortality hypothesis: a test using the cabbage butterfly. Ecology 78, 987-999.

Benrey, B., Callejas, A., Rios, L., Oyama, K. \& Denno, R.F. (1998) The effects of domestication of Brassica and Phaseolus on the interaction between phytophagous insects and parasitoids. Biological Control 11, 130-140.

Berrigan, D. (1991) The allometry of egg size and number in insects. Oikos 60, 313-321.

Bovey, P. (1966) Super-famille des Tortricoidea. Entomologie appliquée à l'agriculture. pp. 456-893 in Balachowsky, A.S. (Eds) Vol. 2 Lépidoptères. Paris, Masson et Cie.

Bulmer, M.G. (1983) Models for the evolution of protandry in insects. Journal of Theoretical Biology 35, 195-206.

Chen, Y.H. \& Welter, S.C. (2003) Confused by domestication: incongruent behavioural responses of the sunflower moth, Homoeosoma electellum (Lepidoptera: Pyralidae) and its parasitoid Dolichogenidea homoeosomae (Hymenoptera: Braconidae), towards wild and domesticated sunflowers. Biological Control 28, 180-190.

Dixon, A.F.G. (1987) Seasonal development in aphids. pp. 315320 in Harrewijn, P. \& Minks, A. (Eds) Aphids: their biology, natural enemies and control. Amsterdam, Elsevier.

Eichhorn, K.W. \& Lorenz, D.H. (1977) Phonologische Entwicklumggsstadien der Rebe. Nachrichtenblatt des Deutschen Pflanzenschutzdienstes 29, 119-120.

Evans, L.T. (1993) Crop evolution, adaptation and yield. Cambridge, Cambridge University Press.

Fagerström, T. \& Wiklund, C. (1982) Why do males emerge before females? Protandry as a mating strategy in male and female butterflies. Oecologia 52, 164-166.

Fermaud, M. (1998) Cultivar susceptibility of grape berry clusters to larvae of Lobesia botrana (Lepidoptera: Tortricidae). Journal of Economic Entomology 91, 974-980.

Fox, C.W. \& Czesak, M.E. (2000) Evolutionary ecology of progeny size in arthropods. Annual Review of Entomology 45, 341-369.

Fox, C.W., Thakar, M.S. \& Mousseau, T.A. (1997) Egg size plasticity in a seed beetle: an adaptative maternal effect. American Naturalist 149, 149-163.

Gabel, B. \& Roehrich, R. (1995) Sensitivity of grapevine phenological stages to larvae of European grapevine moth Lobesia botrana Den. \& Schiff. Journal of Applied Entomology $119,127-130$

Heywood, V. \& Zohary, D. (1995) A catalogue of the wild relatives of cultivated plants native to Europe. Flora Mediterranea 5, 375-415.

Idris, A.B. \& Grafius, E. (1996) Effects of wild and cultivated host plants on oviposition, survival, and development of diamondback moth (Lepidoptera: Plutellidae) and its parasitoid Diadegma insulare (Hymenoptera: Ichneumonidae). Environmental Entomology 25, 825-833.

Karlsson, B. \& Wiklund, C. (1984) Egg weight variation and lack of correlation between egg weight and offspring fitness in the wall brown butterfly Lasiommata negra. Oikos 43, 376-385.

Karlsson, B. \& Wiklund, C. (1985) Egg weight variation in relation to egg mortality and starvation endurance of newly hatched larvae in some satyrid butterflies. Ecological Entomology 10, 205-211.

Kaspi, R., Mossinson, S., Drezner, T., Kamensky, B. \& Yuval, B. (2002) Effects of larval diet on development rates and reproductive maturation of male and female Mediterranean fruit flies. Physiological Entomology 27, 29-38.

Leather, S.R. (1995) The effect of temperature on oviposition, fecundity and egg hatch in the pine beauty moth, Panolis flammea (Lepidoptera: Noctuidae). Bulletin of Entomological Research 84, 515-520.

Leather, S.R. \& Dixon, A.F.G. (1982) Secondary host preferences and reproductive activity of the bird cherry-oat aphid, Rhopalosiphum padi. Annals of Applied Biology 99, 115-118.

Lederhouse, R.C., Finke, M.D. \& Scriber, J.M. (1982) The contributions of larval growth and pupal duration to protandry in the black swallowtaill butterfly, Papilio polyxenes. Oecologia 53, 296-300.

Legendre, P. \& Legendre, L. (1988) Numerical ecology, developments in environmental modelling. 2nd English editions, Amsterdam, Elsevier.

Mackey, A.P. (1978) Growth and bioenergetics of the moth Cyclophragama leucosticta Grunberg. Oecologia 32, 367-376.

Maher, N. \& Thiéry, D. (2004) A bioassay to evaluate the activity of chemical stimuli from grape berries on the oviposition of Lobesia botrana (Lepidoptera: Tortricidae). Bulletin of Entomological Research 94, 27-33.

Maher, N., Jolivet, M. \& Thiéry, D. (2001) Oviposition preference of the European grape vine moth, Lobesia botrana (Lepidoptera: Tortricidae) for different vine cultivars: influence of chemical stimuli from the fruit surface. $I O B C /$ wprs Bulletin 24(7), 103-108.

Marchal, P. (1912) Mission d'étude de la Cochylis et de l'Eudemis pendant l'année 1911. Paris, Librairie Polytechnique.

Mousseau, T.A. \& Fox, C.W. (1998) Maternal effects as adaptations. Oxford, Oxford University Press.

Mondy, N. \& Corio-Costet, M.F. (2000) The response of the grape berry moth (Lobesia botrana) to a dietary phytopathogenic fungus (Botrytis cinerea): the significance of fungus sterols. Journal of Insect Physiology 46, 1557-1564.

O'Brien, D., Fogel, M. \& Boggs, C. (2002) Renewable and nonrenewable resources: amino acid turnover and allocation to reproduction in Lepidoptera. Proceedings of the National Academy of Sciences USA 99, 4413-4418.

Ocete, R., Lopez, M.A., Lara, M. \& Del Tio, R. (1997) Spanish wild grapevine populations: genetic resources and phytosanitary status. Plant Genetic Resources 110, 5-12.

Parry, D., Spence, J.R. \& Volney, W.J.A. (1998) Budbreak phenology and natural enemies mediate survival of firstinstar forest tent caterpillar (Lepidoptera: Lasiocampidae). Environmental Entomology 27, 1368-1374.

Ratte, H.T. (1985) Temperature and insect development. pp. 3366 in Hoffmann, K.H. (Eds) Environmental physiology and biochemistry of insects. Berlin, Springer-Verlag.

Raven, C.P. (1961) Oogenesis the storage of developmental information. Oxford, Pergamon Press. 
Rodriguez-del-Bosque, L.A., Smith, J.W. \& Browning, H.W. (1989) Development and life-fertility tables for Diatraea lineolata (Lepidoptera: Pyralidae) at constant temperatures. Annals of the Entomological Society of America 82, 459-469.

Roehrich, R. \& Boller, E. (1991) Tortricids in vineyards. pp. 507514 in Van der Gesst, L.P.S. \& Evenhuis, H.H. (Eds) Tortricid pests, their biology natural enemies and control. Amsterdam, Elsevier.

Savopoulou-Soultani, M. \& Tzanakakis, M.E. (1988) Development of Lobesia botrana (Lepidoptera Tortricidae) on grapes and apples infected with the fungus Botrytis cinerea. Environmental Entomology 17, 1-6.

Scossiroli, R.E. (1988) Origine ed evoluzione della vitte. Atti, Istituto Botanico della Università Laboratorio Crittogamico 7, $35-55$.

Scriber, J.M. \& Slansky, Jr. F. (1981) The nutritional ecology of immature insects. Annual Review of Entomology 26, 183211.

Slansky, F. \& Scriber, J.M. (1985) Food consumption and utilization. pp. 87-163 in Kerkut, G.A. \& Gilbert, L.I. (Eds) Comprehensive insect physiology, biochemistry and pharmacology. Oxford, Pergamon Press.

Slansky, F. \& Rodriguez, J.G. (1987) Nutritional ecology of insects, mites, spiders, and related invertebrates: an overview. pp. 1-69 in Slansky, F. \& Rodriguez, J.G. (Eds) Nutritional ecology of insects, mites, spiders, and related invertebrates. New York, Wiley.

Stellwaag, F. (1928) Die Weinbauinsekten der Kulturländer. Berlin, Paul Parey.

Thiéry, D. (2005) Vers de la grappe. Les connaître pour s'en protéger. Guide pratique, Vigne et vins. Int. Publication, Bordeaux France.

Thiéry, D. \& Gabel, B. (2000) Comportement de ponte des femelles de l'eudémis de la vigne en présence d'extraits de fleur de "Muller Thurgau". IOBC/woprs Bulletin 23(4), 135-138.
Thiéry, D. \& Moreau, J. (2005) Relative performance of European grapevine moth (Lobesia botrana) on grapes and other hosts. Oecologia 143, 548-557.

Torres-Vila, L.M., Stockel, J. \& Roehrich, R. (1995) Le potentiel reproducteur et ses variable biotiques associées chez le mâle de l'Eudémis de la vigne Lobesia botrana. Entomologia Experimentalis et Applicata 77, 105-119.

Torres-Vila, L.M. \& Rodriguez-Molina, M.C. (2002) Egg size variation and its relationship with larval performance in the Lepidoptera: the case of the European grapevine moth Lobesia botrana. Oikos 99, 272-283.

Van Emden, H.F. (1987) Cultural methods: the plant. pp. 27-68 in Burn, A.J., Coaker, T.H. \& Jepson, P.C. (Eds) Integrated pest management. London, Academic Press.

Wiklund, C. \& Fagerström, T. (1977) Why do males emerge before females? Oecologia 31, 153-158.

Wiklund, C. \& Persson, A. (1983) Fecundity, and the relation of egg weight variation to offspring fitness in the speckled wood butterfly Pararge aegeria, or why don't female butterflies lay more eggs? Oikos 40, 53-63.

Wiklund, C., Nylin, S. \& Forsberg, J. (1991) Sex-related variation in growth-rate as a result of selection for large size and protandry in a bivoltine butterfly, Pieris napi. Oikos 60, 241-250.

Wiklund, C., Kaitala, A., Lindfors, A. \& Abenius, V. (1993) Polyandry and its effect on female reproduction in the green-veined white butterfly (Pieris napi L.). Behavioural Ecology and Sociobiology 33, 25-33.

Weseloh, R.M., Andreadis, T.G., Moore, R.E.B., Andersson, J.F., Dubois, N.R. \& Lewis, F.B. (1983) Field confirmation of a mechanism causing synergism between Bacillus thuringiensis and the gypsy moth parasitoid, Apanteles melanoscelus. Journal of Invertebrate Pathology 41, 99-103.

(Accepted 11 November 2005)

(C) CAB International, 2006 